\title{
Zeugizō: The Language of Marital Infidelity in the Account of Treachery Toward the Ancestral Laws in 1 Macc 1:15
}

\author{
JANUSZ NAWROT \\ Adam Mickiewicz University in Poznań \\ jannaw@amu.edu.pl, ORCID: 0000-0002-2498-5081
}

\begin{abstract}
The present article deals with a linguistic issue well known in the Bible but not usually overtly present in the terminology of Hebrew and Greek Scripture. It concerns the sexual sphere of human life and is expressed by the verb zeugizō (1 Macc 1:15). This term appears only once in the Septuagint and is not featured in any of the other inspired books. However, the discovery of a non-biblical text which includes the term in question, as well as the inclusion of the verb by the Jewish authors of the Greek Bible from the 2nd century AD, shed important light on the sense of the verb in the First Book of the Maccabees. The exegesis carried out reveals just how harsh was the hagiographer's critique of, and judgment upon, the supporters of the Hellenization of Judea.
\end{abstract}

Keywords: Old Testament, Septuagint, The First Book of Maccabees, sexuality, idolatry

There is no doubt that sexuality is one of the most important aspects of human existence. This complex area is weakened after the tragedy of original sin and is susceptible to different manipulations, redefinitions and new concepts. All of these facilitate the reduction or even the elimination of responsibility for one's sexual conduct. The biggest threat to the truth taught by the Church could be relativism applied to the one truth given by Jesus. In the context of warnings formulated by Jesus and the Apostles, ${ }^{1}$ this relativism will be a sign of the last days.

This article proposes to follow the same track without stressing adultery or infidelity as is done by the major prophets in the Old Testament. Instead, the phenomenon of sexual intercourse between a man and woman will be underscored. This intercourse is most likely not bound by a marital relationship, but instead results purely from lust and emotional passion. Moreover, it is expressed with the use of the verb zeugizo which occurs only three times in Greek literature and also appears in 1 Macc 1:15. This minimal number of cases makes one wonder why the verb was used in the inspired text and why it is a hapax legomenon of the Septuagint, especially when one considers that, to this day, no one has discovered the mentioned verb in

$1 \quad$ Matt 24:11-12; Mark 13:22; Acts 20:30; 2 Cor 11:13-15; 2 Thess 2:3; 1 Tim 4:1-2; 2 Tim 4:2-4. 
other Greek written texts. This very question is the principle of the following exploration of the uses of the term that will encompass three stages:

1. determining the meaning of the verb zeugizō on the basis of an ancient text from Hellenistic literature

2. determining the role of the verb in the main verse of 1 Macc 1:15 and its influence on the sense of the message conveyed by the hagiographer

3. the revelation of the semantic scope of zeugizo in Num 25:1 in the Bible translations of Aquila and Theodotion

In each of these stages, we will examine the meaning of the same term within these three different texts.

\section{Paraclausithyron of Alexandria}

In order to better understand the significance of erotic poetry, it is noteworthy that Alexandria was an important center of this type of literature in antiquity. This poetry reveals quite a developed sensual lifestyle of inhabitants of this cosmopolitan city like it was in Babylon. Alexandria was the city where hetero-, bi - and homosexuality were all openly practiced and were all expressed in the literature produced there. ${ }^{2}$ The status of women in this city was exceptional in those times, involving a life of great liberty, a sense of personal freedom and the possibility of holding public offices. ${ }^{3}$ It is not surprising that erotic poetry which praises human love also in its physical form existed and was combined with emotional passion and lust. In antiquity, Alexandria and Rome became bastions of love and erotic poetry thanks to people like Asclepiades, Theocritus, Meleager and Callimachus. ${ }^{4}$

Paraclausithyron is a literary genre known in the ancient literature of both Greece and Rome. As the very name indicates, it consists in lamenting and pining for a lover who stands behind the closed door and wants to come inside. ${ }^{5}$ The following text, an example of this genre which most likely comes from the $2^{\text {nd }}$ cent. BC, ${ }^{6}$ reads:

2 Gregory, H.D. and Hellenism, 51. Edmund Keeley discusses the sensuality of this ancient metropolis and its impact on the works of the twentieth-century Greek poet Constantine Cavafy in his Cavafy's Alexandria, 43-74.

3 Pomeroy, Women in Hellenistic Egypt, 41-82.

4 Paz, The Double Flame, 28-52; Lambert, "Alexandria," 46-47.

5 The name is most likely a combination of the verb paraklaio - "weep in front of" - and thyra - "a door." Howard V. Canter discusses it broadly in "The Paraclausithyron as a Literary Theme," 355-368; Maligec, “The Raven' as an Elegiac Paraclausithyron," 87-97. This form was utilized by Horace, Tibullus, Propertius and Ovidius in Latin poetry.

6 Researchers date this text more accurately between 173 and 100 BC, see Grenfell, An Alexandrian Erotic Fragment, 1. 
From both of us was the choice: we were united (ezeugismetha)

Cypris is the surety of our love.

Grief holds me fast when I remember how he traitorously kissed me, meaning to desert me all the while, the contriver of inconstancy.

Love, the establisher of friendship, overcame me;

I do not deny that I have him ever within my soul.

Ye dear stars, and thou, lady night, partner of my love,

bring me even now to him to whom Cypris leads me as slave

and the great love that has taken hold upon me (Paracl. 1-8) ${ }^{7}$

Before discussing the stanzas above, it is noteworthy that the original context of the verb zeugizo is most likely not sexual. The word in question is a derivative of zeugnymi - "I yoke up, I yoke together" implicitly refers to "a pair of animals." Thus, the verb only means "to unite a woman with her husband" in the metaphorical way. ${ }^{9}$ Apart from the inspired texts where zeugnymi occurs, there is also a deverbative noun zeugitès which denotes a member of an economic social group in ancient Athens. It literally means "the one who has a yoke (zeugos) for a pair of oxen." a result, there was a separate social or military stratum in Greek society. It was a community of interests, actions or concrete obligations called zeugitai. ${ }^{11}$

Contrary to the majority of examples of the paraclausithyron genre, in the text quoted above it was the woman who was betrayed and abandoned. In this situation, she could only stand behind the door of her beloved and pine for him, remembering moments of passionate love combined with anger experienced because of the situation that arose. The vocabulary speaks of erotic love between a man and woman, combining both sexual and emotional elements. These elements occur in a body desirous of another meeting and caress. Thus, there is an agreement of emotions between lovers (philia, v. 1), "a fire (poly pyr) ${ }^{12}$ kindling their souls" (psyche kaiomenos, v. 9), the suffering of a lover (adikeō, v. 10), a feeling of burning out (katakaiomai, v. 13), a lover (kyrios, v. 16) or finally a flame of one's own emotions (eudokō zè $\bar{l} \bar{o}$, v. 17). ${ }^{13}$ The intensity of these emotions is best expressed by the verb kataphileō which means "tender kisses." When looking at the relics of Greek literature, it is noteworthy that the verb in question is not treated symbolically but literally

\footnotetext{
Translated after Longus, Daphnis and Chloe, 377.

Gen 46:29; Exod 14:6; 2 Sam 20:8; 1 Kgs 6:7,10; 18:44; 2 Kgs 9:21; Jdt 15:11.

Bailly, Dictionnaire grec-français, 880.

Aristotle, Constitution of the Athenians VII, 4.

Aristotle, Politics II, 1274a.20; Diodorus, Bibliotheca Historica XVII, 71.2; Demosthenes, Speeches 43.54; Aristotle, Constitution of the Athenians IV, 3; VII, 3; Thorley, Athenian Democracy, 14, 30.

12 There is a similar meaning in Hymn 2 to Demeter II, 248.

13 For a wider discussion on the meanings of particular termse, see Rivier, Études de littérature grecque, 238 n. 15.
} 
even though not all kisses express these emotions or lust. ${ }^{14}$ The distinctive context of the vocabulary denotes erotic love directly relates the verb zeugizo, "I bind, unite" to sexual intercourse whose guarantor is both Aphrodite, the goddess of erotic love, and Eros, her son, the god of lust and sexual ecstasy. ${ }^{15}$ In the analyzed text, the goddess is called "Kypris," similarly to Sappho, the best known creator of love lyric. ${ }^{16}$

Still, who are the two lovers and how did they meet for the first time, fall in love and ultimately break up? While the poem does not explain this in a clear way, it is safe to assume that they could have been single or married, which also means, therefore, that they could have committed adultery. Neither of these hypotheses is inconsistent with the fragment above. However, it can be safely stated that the feeling expressed, albeit intense, turned out to be dishonest and transitory. It was also focused on a momentary, egotistical and mainly sexual pleasure, as it is described in verses 3 and 4 . Ultimately, this pleasure, combined with dishonesty and exploitation, led to the tragedy of betrayal where one party wanted to end the relationship suddenly.

\section{The Meaning of zeugizō in 1 Macc 1:15aß-b}

Verse 15 provides a theological summary of the earlier actions of the Jewish dissenters from the faith of the whole community (v. 11-14). In as much as the author is not only a historian but a person of faith, he sees a great hazard to the faith of the whole community in the behavior of the dissenters. The verse in question reads as follows:

they abandoned the holy covenant

and allied themselves (ezeugisthēsan) with other nations

and sold themselves to wrongdoing.

The author is convinced that the conduct of the Jewish supporters of Antiochus IV breaks the covenant made between God and their ancestors (Gen 17:3-8) and the covenant made on Mount Sinai (Exod 24:3,7) when the people agreed unanimously to observe everything that the Lord had commanded them to do. ${ }^{17}$ Moreover,

14 In the same sense as an expression of temperament, Xenophon, Cyropaedia VI, 4,10; Epictetus, Enchiridion III; Plutarch, Pericles XXIV, 6; Demetrius XIX, 4; Antonius X 5; LXX, 1; LXXIV, 3; Aemilius Paulus X, 4; Marcus Cato XVII, 7. Kisses related to customs or occassions, Epictetus, Speeches I, 19,24; II, 22,13; III, 7,31,85,88; IV, 1,17; Plutarch, Brutus XVI, 4; Fabius Maximus XIII, 5; Mulierum virtutes I.

15 Calame, The Poetics of Eros in Ancient Greece, passim for a great discussion of the role of both gods in initiating and complementing physical love of a man, as well as combining the fleshly, emotional and spiritual elements of human love.

16 Sappho, Poems and Fragments, 6, 10. The verse is similar to Ezek 23:21 in its description of caress and acts during a sexual intercourse.

17 Fairweather - Sutherland Black, The First Book Of Maccabees, 60. 
there is the expression diathēke hagia which occurs in the Greek text of Dan 11:28,30. The form apestēsan - "they deserted, went away" - is frequently used in the Septuagint to portray the attitude of rebellion and abandonment of God by His kings and the whole people. ${ }^{18}$ Therefore, the Hellenists continue the centuries-old rebellion of the chosen people against their God. When it comes to the covenant with Abraham, their activity contradicts the roots of Israel who is Abraham's offspring according to the promise based on circumcision. Whereas the Hellenists descended from the patriarch according to the flesh, they excluded themselves from the inheritance conditioned by circumcision. Entering into a relationship with other nations by dissension complements the earlier process of their leaving the holy covenant between God and Israel.

As was stated earlier, the verb zeugizō occurs only once in the Septuagint in the verse in question from the First Book of Maccabees. If the Paraclausithyron of Alexandria contains it in the literal sense to mean sexual intercourse between a man and woman, it is presently used in a new and foreign context. Yet, it retains the whole meaning of the original context. The hagiographer uses this meaning with regard to relations between Jewish dissenters from the Law of Moses and Gentiles or more specifically the Greek stratum of the Jerusalem community. It is important to underscore the sharp nature of the sorrow of the betrayed and abandoned lover who inhabited the cosmopolitan city with regard to the relationship between God and Israel. This betrayal has to do with an illegitimate relationship that originated at the cost of fidelity from a former partner. Such are the Jewish renegades who departed from the Law, as it is described in the first part of verse 15 presented above. Their engagement with the Gentiles was established because of departure from the Law and the covenant. As the analysis of the Paraclausithyron of Alexandria showed, there are three similar theological themes within 1 Macc:

- the betrayal of a spouse/lover by the other side

- the transitory nature of affection and egoism of one side

- the unilateral dishonesty of an unlawful and unsuccessful relationship combined with a sense of infidelity of the deceived side

The comparison of idolatry to adultery was introduced by Hosea in the Old Testament. In 2:4, he writes about adultery (zenûnîm) and promiscuity (na'apîpîm) of the whole people toward the God of Israel. He also describes this in 3:1.19 Thus, Israel loses the right to the legitimate name of "the Lord's people" or "the chosen people." 20 The passage of Ezek 23:22-29 likens idolatry to prostitution (zimmâ,

182 Chr 29:6; 30:7; Neh 9:26; Jdt 5:18; Jer 2:5; 5:25; Jer (LXX) 40:8; Bar 3:8; Ezek 20:8; Dan 9:11; Deut 32:15; Josh 22:19,23,29; 2 Chr 26:18; 28:22; Isa 59:13.

19 Exod 34:15-16; Lev 17:7; 20:5-6; Num 25:1-2; Deut 31:16; Judg 2:17; 8:33; 1 Chr 5:25; Hos 4:12; 9:1. All of these examples include the use of the main stem $z \bar{a} n \hat{a}$ - "to commit adultery, to prostitute oneself." Jer 5:7; 7:9; Hos 3:1, on the other hand, utilize the stem näap which means the same.

20 Garrett, Hosea, 79. 
v. 27,29; zenûnim, taznût, v. 29) which the Greek Bible most frequently describes with the word porneia. ${ }^{21}$ These comparisons were made by the prophets ${ }^{22}$ so as to severely define the wickedness and revolting consequences of such actions taken by the chosen people (Hos 4:12-14; Jer 3:1-10; Ezek 16:15-34; 23:1-21). ${ }^{23}$ In the Septuagint, the main verb which describes this behavior is ekporneuo - "I prostitute myself, I commit adultery." 24

It seems that the utilization of the verb zeugizo is supposed to show a close relationship between both elements - the Hellenists and foreign nations whose objectives are mutual and tightly united. In the historical context of 1 Macc, these objectives, meant for the welfare of the whole community, are actually to the detriment of the chosen people. What is represented by this one verb only is later extended by an important idolatrous element in 1:43 - making idolatrous offerings and desecrating the Sabbath. In verse 47, there are other forms of idolatry - illegitimate altars, sacred groves, idol statues, and offerings made with impure animals. By doing so, the Hellenists join the centuries-old disgraceful tradition of the people's betrayal against their Lord, which was fiercely criticized by the prophets. The actions of the Jewish supporters of the Hellenization of the country, in cooperation with the representatives of the Greek establishment in Judea, completely deprive the former of the right to be called the people of the God of Israel.

The ending expression and [they] sold themselves to wrongdoing presents the actions of the Jewish dissenters who are against their own nation. They expected esteem and social or economic privileges in the Greek community from following a pagan lifestyle. A certain group of dissenters tried to follow the so-called "Hellenistic Judaism" known to the Jews from the Diaspora who spoke and wrote in Greek. This type of Judaism consisted in the falsification of their religion and the combination of Greek ideas with their faith, which ultimately led to syncretism. ${ }^{25}$

The verb zeugizo accentuates the freedom to cooperate with the supporters of the Hellenization of the people and the representatives of the Seleucid king in Judah. Both sides derive a peculiar pleasure from this cooperation similar to that of sexual intercourse. There is also the satisfaction from this cooperation combined with anticipated social benefits.

21 Num 14:33; 2 Chr 9:22; Wis 14:12; Hos 2:4,6; 4:11-12; 5:4; 6:10; Mic 1:7; Nah 3:4; Isa 47:10; 57:9; Jer 2:20; 3:2,9; 13:27; Ezek 16:15,22,25,33-34,36,41; 23:7-8,11,14,17-19,27,29,35; 43:7,9.

22 Richard M. Davidson (Flame of Yahweh, passim) discusses sexuality on a personal, family and social plane in the Old Testament.

23 This is most likely about severe suffering of the betrayed side, which in this case is God Himself symbolized by the beloved husband, Halbertal - Margalit, Idolatry, 9-36, esp. 10, 18.

24 Exod 34:15-16; Lev 17:7; 20:5-6; Num 25:1; Deut 31:16; Judg 2:17; 8:27,33; 2 Chr 21:11,13; Sir 46:11; Hos 4:12-13,18; 5:3; Jer 3:1; Ezek 6:9; 16:16-17,20,26,28,30,33; 20:30; 23:3,5,30,43. 


\section{The Utilization of zeugizō in Num $25: 3$ in Aquila's and Theodotion's Translations}

The last point of this article concerns the translation of the Hebrew Bible into Greek much later - in the $2^{\text {nd }}$ cent. AD - by Aquila of Sinope, a Jewish proselyte and a disciple of the famous Rabbi Akiva. ${ }^{26}$ In turn, Theodotion was most likely born in Ephesus and lived in the $2^{\text {nd }}$ cent. $\mathrm{AD}$. He created his great translation in $180-190 .{ }^{27}$ It is widely believed that the Greek version of the Bible translated by Aquila originated before Adversus Haereses by Irenaeus of Lyon ca. 177 AD. ${ }^{28}$ Currently, there is no comprehensive version of any of these works but there are large fragments of Hexapla by Origen who included the Hebrew original and its Greek transliteration, the Septuagint and Symmachus's version, as well as the Greek versions of Hebrew Scripture complied by Aquila and Theodotion. Luckily, Num 25:3 was preserved in its entirety in both works. It reads as follows:

\section{Thus Israel yoked itself (ezeugisthē) ${ }^{29}$ to the Baal of Peor,}

and the LORD's anger was kindled against Israel.

The verb zeugizō was used as a Greek counterpart of the Hebrew root șāmad which typically means "to be involved with" or more specifically "to follow a god, (...) to bear the yoke of a god, to serve him" ${ }^{\prime 30}$ in the stem nipal. The first part of v. 3 in the Hebrew version might be translated as follows:

Thus Israel clung [wajișsāmed] to the Baal of Peor,

and the LORD's anger was kindled against Israel.

Apart from the quoted verse of Num 25:3, the verb derived from the mentioned root can only be found in the Bible in several verses. The verb also occurs in the stem nipal - "to join" - in Num 25:3. Ps 50:19, on the other hand, translates the stem hip'il as "to yoke, to tighten." Ps 106:28 relates the same story as Num 25:3 but changes nipal for a stronger hip'il. Finally, 2 Sam 20:8 translates șämad as "buckled on" in the sense of "attaching a sword to armor" in the stem pu'al. It seems that the transla-

\footnotetext{
26 For a broader discussion of this author and his work, see Labendz, "Aquila’s Bible," 353-388.

27 Frederick Field discusses both Jewish translators in his work Origenis Hexaplorum, XVI-XXVII and XXXVIII-XLIII.

28 The alleged date of Aquila's work negates the possibility of borrowing its content by the author of 1 Macc like it was erroneously noted in the commentary to this book, Nawrot, Pierwsza Ksiega Machabejska, 315. This article attempts to correct this interpretation error.

29 Codex Mediolanensis based on Aquila's and Theodotion's texts contains ezeusthe - a deverbative of zeugnymi - which has the same lexical meaning, McClurg, A Critical Edition, 196.

30 HALOT III, 1032.
} 
tors did not see any sexual connotation of the verb șāmad in any of the texts. It is still possible that this element occurs in the Hebrew language. ${ }^{31}$ The Samaritan version of the Book of Numbers is meaningful here. The translators of Num 25:3 write directly "they were yoked to the Baal of Peor" with a strong implication of sexual intercourse. ${ }^{32}$

The Septuagint uses etelesthe to express the stem above. Some researchers translate the term teleo as "to be introduced to, for instance, the arcana of mystery worship ${ }^{33}$ which is well attested in classical Greek. ${ }^{34}$ The speech of Demosthenes On the Crown 259 and the speech of Herodotus The Histories IV, 79 deserve special attention. In the latter, teleo occurs in the context of debauchery during bacchanalia. Similarly, the bacchic mystery was also discussed in Aristophanes's play titled The Frogs 357. The examples discussed above allow for the application of a sexual connotation also in the case of the verb teleo. It is also noteworthy that teleo occurs in the religious sense only in Num 25:3,5 and Ps 105:28 (LXX) in relation to idolatrous worship in the Greek bible. Thus, the verb receives an extremely negative connotation of "going into service to a god." 35 It might be claimed, therefore, that the semantic areas of teleō and zeugizō in Num 25:3 overlap considerably in the Septuagint, and the versions of Aquila and Theodotion. Additionally, zeugizo should be understood in the metaphorical sense.

As verses 1-3 do not include differences in vocabulary between the Septuagint and Aquila's and Theodotion's versions, it could be claimed that both translations are the same. ${ }^{36}$ Roughly speaking, it enables one to carry out a further exegesis of both translations according to the Greek Bible. The context of v. 1-16 clearly indicates that the misdeeds of the Israelites with female Moabites consisted in eating meals dedicated to a Gentile idol combined with sexual debauchery (v. 6-8). In v. 1 the vile behavior of the Israelites was defined with the stem $z \bar{a} n \hat{a}$ - "to commit adultery" - which is a reference to Lev 17:7 and Deut 31:16. Both verses link idolatry with adultery understood symbolically. ${ }^{37}$ This is also confirmed in the Greek Bible where the verb ekporneuo - "I commit adultery, I prostitute myself" - is used in the verses mentioned above. This borrowing from the lives of female prostitute is obvious. ${ }^{38}$ There is no doubt that the terms porneia and ekporneuo show worship infidelity of

31 Field (Origenis Hexaplorum, 257) translated wajișsāmed into the Latin expression copulatus est which points to the sexual meaning of the Hebrew stem. Jules de Vaulx (Les Nombres, 299) is also convinced of the sexual connotation of the verb based on some naturalistic rituals of fertility gods known in antiquity that were accompanied by sacred prostitution; Budd, Numbers, 279.

32 Phillips, The Samaritan Version, 143.

33 "be initiated (e.g. into cult mysteries)," McClurg, A Critical Edition, 195.

34 LSJ, 1171.

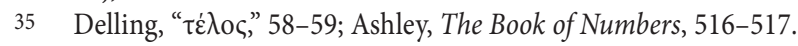

36 Field, Origenis Hexaplorum, 257.

37 McKenzie, Idolatry in the Pentateuch, 106.

38 This is pointed out by Gen 38:24; Lev 19:29; 21:9; Deut 22:21; Hos 1:2 and 2,7, where the verb in question was used in the literal sense of committing adultery by female Israelites. 
the chosen people toward their God ${ }^{39}$ which was taking root in the Canaan cults. Additionally, the combination of ekporneuo with the worship verb proskyneo - "to make an obeisance, to bow" - which occurs in Num 25:1-2 points to the same theology as Exod 34:15-16 and Judg 2:17. The former possesses the same two leading elements as Num 25:1-3, namely making offerings to gods combined with their consumption and seduction of men through sacred prostitution. The core of this infidelity can be described easily: like a prostitute who sells herself for money and shows infidelity toward her husband, so the people act when they make offerings and seek a blessing from different gods, being radically unfaithful to their Lord. ${ }^{40}$ The combination of ekporneuō and eidōlon - "a god" - which occurs in Num 25:1-2 is also visible in Hos 4:17-18 and Ezek 16:15-18 in the same context of idolatry understood as adultery. The combination of ekporneū and thysia - "an offering" - also occurs in Lev 17:7 in the same context of idolatry. Finally, the terms ekporneuō and orgizō "I am angry" - can be found in Deut 31:16-17 where they are the Lord's answer to the sacred prostitution committed in Israel. Some exegetes link Num 25:1-16 to similar textual structure in Gen 34 which contains the same elements of sexual abuse committed by Gentiles on Dinah, the sister of Jacob's sons. They reacted violently to the defilement of their sister by killing the wrongdoers ${ }^{41}$ like Phinehas who punctured the wombs of unfaithful adulterers. The comparison above indicates that the Septuagint, along with Aquila's and Theodotion's versions, carry the same theology of idolatry understood as adultery and infidelity of the chosen people toward their Lord, the faithful beloved.

Both of these versions stress idolatry as vile copulatio of Israel with Gentile idols similar to a female lover who abandons her husband and derives pleasure from illegitimate intercourse. This idolatry is expressed through the use of the verb zeugizo, more so in the mentioned versions than in the Greek Bible.

\section{Conclusion}

Both the Paraclausithyron of Alexandria and the versions of Aquila and Theodotion illustrate very well the conduct of the Hellenists in 1 Macc 1:15. Greek ideas influence them like Gentile prostitutes. After getting to know them, the Hellenists adopt them as if they were their own not unlike the chosen people who did so during the Exodus. What should be stressed here is their vile desire for what is out of line with the Law of Moses. Just as immoral lovers do not bear real love, fidelity and

\footnotetext{
39 Hauck - Schulz, “лó $\rho v \eta, " 584-587$.

40 Stuart, Exodus, 724-726.

41 Carmichael, The Book of Numbers, 137-140.
} 
honesty toward their life partners, the Hellenists do not care about observance of the Law and faithfulness toward the God of Israel. By feeling a burning desire for social advancement promoted by the Greeks, they are ready to become wicked and reject the obligations imposed on them by the Law and the tradition of their own people. The sexual promiscuity of ancient Gentiles often linked to cultic initiations and related to the mysteries of different idols was well known (Lev 18:6-23). This was a fundamental reason why God commanded His people to distance themselves from any such practices (Exod 34:14-16). Such norms of conduct were one of the reasons why the Gentile peoples had been expelled from the Promised Land (Gen 15:16; Lev 18:24; Deut 9:4-5; 12:31; 18:12). Allying with the Gentiles in the history of Israel should be evaluated in the same unequivocal way; it is a duplication of the sin of prostitution that the chosen people committed in the land that was supposed to be a gift from their Lord. By opposing His advice, the renegades deprived themselves of their special membership and rejected the Lord's blessings which resulted from this membership. They also lost the right to reside in the land that He gave Israel in exchange for their observance of His commandments (Deut 8:19-20; 30:1-3,17-18; Josh 23:15). They did not heed the consequences of their own behavior and gave in to the pleasures of the moment. The short-sightedness of this attitude would bring them misery in the form of a rebellion by the Jewish patriots who would expel them from their homes. Thus, the Lord's prognostication would be realized; the people would not tarnish their land with idolatrous prostitution as they could only inhabit the land on the condition that they stayed faithful to His law.

\section{Bibliography}

Ashley, T.R., The Book of Numbers (New International Commentary on the Old Testament; Grand Rapids, MI: Eerdmans 1993).

Bailly, A., Dictionnaire grec-français (Paris: Hachette 1963).

Budd, J., Numbers (Word Biblical Commentary 5, Waco, TX: Zondervan 1984).

Calame, C., The Poetics of Eros in Ancient Greece (Princeton, NJ: Princeton University Press 1999).

Canter, H.V., "The Paraclausithyron as a Literary Theme," American Journal of Philology $41 / 4$ (1920) 355-368.

Carmichael, C., The Book of Numbers. A Critique of Genesis (New Heaven - London: Yale University Press 2012).

Cohen, S.J.D., From the Maccabees to the Mishnah (Louisville, KY: Westminster - John Knox Press 1987).

Davidson, R.M., Flame of Yahweh. Sexuality in the Old Testament (Peabody, MA: Hendrickson 2007). 


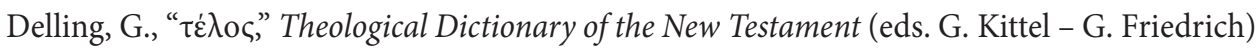
(Grand Rapids MI: Eerdmans 1972) VIII, 49-87.

Fairweather, W. - Sutherland Black, J., The First Book Of Maccabees. With Introduction and Notes (Cambridge: Cambridge University Press 1897 reprint).

Field, F., Origenis Hexaplorum Quae Supersunt, Sive Veterum Interpretum Graecorum in Totum Vetus Testamentum Fragmenta (Hildesheim: Olms 1875) I.

Garrett, D.A., Hosea - Joel. An Exegetical and Theological Exposition of Holy Scripture (The New American Commentary 19; Nashville, TN: Broadman \& Holman 1997).

Gregory, E., H.D. and Hellenism. Classic Lines (Cambridge Studies in American Literature and Culture; Cambridge: Cambridge University Press 1997).

Grenfell, B.P., An Alexandrian Erotic Fragment and Other Greek Papyri Chiefly Ptolemaic (Oxford: Clarendon Press 1896).

Halbertal, M. - Margalit, A., Idolatry (Cambridge, MA - London: Harvard University Press 1994).

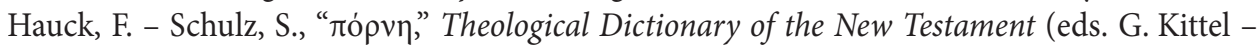
G. Friedrich) (Grand Rapids, MI: Eerdmans 1968) VI, 579-595.

Keeley, E., Cavafy's Alexandria (Princeton, NJ: Princeton University Press 1996).

Koehler, L. - Baumgartner, W. - Stamm, J.J., The Hebrew and Aramaic Lexicon of the Old Testament (trans. M.E.J. Richardson) (Leiden: Brill 1994-2000) I-IV(=HALOT)

Labendz, J.R., "Aquila's Bible Translation in Late Antiquity: Jewish and Christian Perspectives," The Harvard Theological Review 102/3 (2009) 353-388.

Lambert, M., "Alexandria," Gay Histories and Cultures. An Encyclopedia (ed. G. Haggerty) (New York - London: Routledge 2012) 46-47.

Liddell, H.G. - Scott, R. - Jones, H.S., Greek-English Lexicon. With a Revised Supplement, 9 ed. (Oxford: Clarendon 1996) (=LSJ).

Longus, Daphnis and Chloe. Love Romances and Poetical Fragments. Fragments of the Ninus Romance (trans. G. Thornley - J.M. Edmonds - S. Gaselee) (Loeb Classical Library; London: Heinemann - New York: Putnam's Sons 1916) https://archive.org/details/daphnischloewith00longuoft/page/376/mode/2up [access: 16.01.2020].

Maligec, C.F.S., “'The Raven’ as an Elegiac Paraclausithyron,” Poe Studies 42 (2009) 87-97.

McClurg, A.H., A Critical Edition of the Hexaplaric Fragments of Numbers 19-36 (Diss. Faculty of The Southern Baptist Theological Seminary; Louisville 2011).

McKenzie, T.J., Idolatry in the Pentateuch. An Innertextual Strategy (Eugene, OR: Pickwick 2010).

Nawrot, J., Pierwsza Ksiega Machabejska. Rozdziały 1,1-6,16. Wstęp - przekład z oryginału komentarz (Nowy Komentarz Biblijny. Stary Testament 14/1; Częstochowa: Edycja Świętego Pawła 2016).

Paz, O., The Double Flame. Love and Eroticism (San Diego, CA - New York - London: Harcourt \& Brace 1995).

Phillips, D.L., The Samaritan Version of The Book of Numbers with Hebrew Variants. A Close Textual Study (Lewiston, NY - Lampeter: Mellen 2014).

Pomeroy, S.B., Women in Hellenistic Egypt. From Alexander to Cleopatra (New York: Schocken 1984).

Rivier, A., Études de littérature grecque (Université de Lausanne. Publications de la Faculté des lettres 21; Genève: Droz 1975). 
Sappho, Poems and Fragments (trans. S. Lombardo) (Indianapolis, IN: Hackett Publishing Company 2002).

Stuart, D.K., Exodus. An Exegetical and Theological Exposition of Holy Scripture (The New American Commentary 2; Nashville, TN: Broadman \& Holman 2006).

Thorley, J., Athenian Democracy (Lancaster Pamphlets in Ancient History; London - New York: Routledge 1996).

de Vaulx, J., Les Nombres (Sources bibliques; Paris: Gabalda 1972). 